\title{
Evaluation of Socio-Economic Factors that Determine Adoption of Climate Compatible Freshwater Supply Measures at Farm Level: a Case Study in the Southwest Netherlands
}

\author{
Jeroen A. Veraart ${ }^{1} \cdot$ Rianne van Duinen ${ }^{2,3} \cdot$ Jan Vreke $^{1}$ \\ Received: 11 September 2014 / Accepted: 7 June 2016/ \\ Published online: 27 June 2016 \\ (C) The Author(s) 2016. This article is published with open access at Springerlink.com
}

\begin{abstract}
The availability of freshwater resources in soil and groundwater bodies in the southwestern part of The Netherlands is expected to decrease during the agricultural growing season because of an expected increase of freshwater demands and a changing climate. This expected shortage of fresh water might negatively affect agricultural production. To cope with this problem, three pilots were initiated aimed at increasing freshwater supply at farm-level. The objective of this paper is to evaluate the socio-economic factors that determine the wider use of the measures investigated in these pilots. Therefore, the results of a feasibility study and a survey about drought risks were compared. The survey indicates that respondents do not make distinction between a dry and extremely dry year in their estimation of the return period. The results of a feasibility study illustrate that confidence and the level of common understanding regarding the reliability of these innovative measures has increased amongst project participants since 2012. The survey respondents were less optimistic about the wider implementation of the investigated technologies. A reliable freshwater supply and supportive legislation are the most decisive socio-economic factors for a future investment in additional freshwater supply for farmers in this region. Both studies illustrate that the impact of additional freshwater supply on farm economics strongly depends on farm type and crop cultivation plan. These insights may support the wider use of these innovations and may help to improve agrohydrological models.
\end{abstract}

Electronic supplementary material The online version of this article (doi:10.1007/s11269-016-1399-2) contains supplementary material, which is available to authorized users.

Jeroen A. Veraart

jeroen.veraart@wur.nl

1 Alterra, Wageningen University and Research Centre, PO Boxs 47, 6700 AA, Wageningen, The Netherlands

2 Deltares, PO Boxs 177, 2600 MH, Delft, The Netherlands

3 University of Twente, PO Boxs 217, 7500 AE Enschede, The Netherlands 
Keywords Freshwater supply $\cdot$ Agriculture $\cdot$ Adoption $\cdot$ Knowledge $\cdot$ Climate $\cdot$ Adaptation

\section{Introduction}

Under average climatic conditions, freshwater supply for Dutch agriculture is excellent. A large part of Dutch agricultural areas can be supplied with water from the rivers (Fig. 1). However, in situations with a low river discharge and a high precipitation deficit, it is possible that the freshwater supply cannot meet agricultural freshwater demand during the growing season. This is particularly true for the rain-fed agricultural areas in the southwestern part of the Netherlands (Fig. 1) that have no access to river water. These agricultural areas, situated below sea level, are also sensitive to salt water intrusion (Cominelli et al. 2013; De Louw 2013; De Louw et al. 2011; Van Bakel et al. 2009).

The Netherlands usually has a precipitation deficit in summer (average $100 \mathrm{~mm}$ ) and a precipitation surplus in winter. In the coastal zone, the precipitation deficit in spring and early summer is usually larger than in the rest of the country, whereas the situation is reversed in late summer and autumn (Van Minnen and Ligtvoet 2012). The annual cumulative maximum precipitation deficit occurs during the summer half-year from April to September (Beersma and Buishand 2004).

In the southwest of the Netherlands there are about 5500-6000 farms, of which $50 \%$ perform arable farming, $12 \%$ horticulture and $6 \%$ greenhouse horticulture (CBS \& LEI 2014). In 2012, total turnover amounted to some 1.3 billion euro (Visser \& van Tuinen 2012).
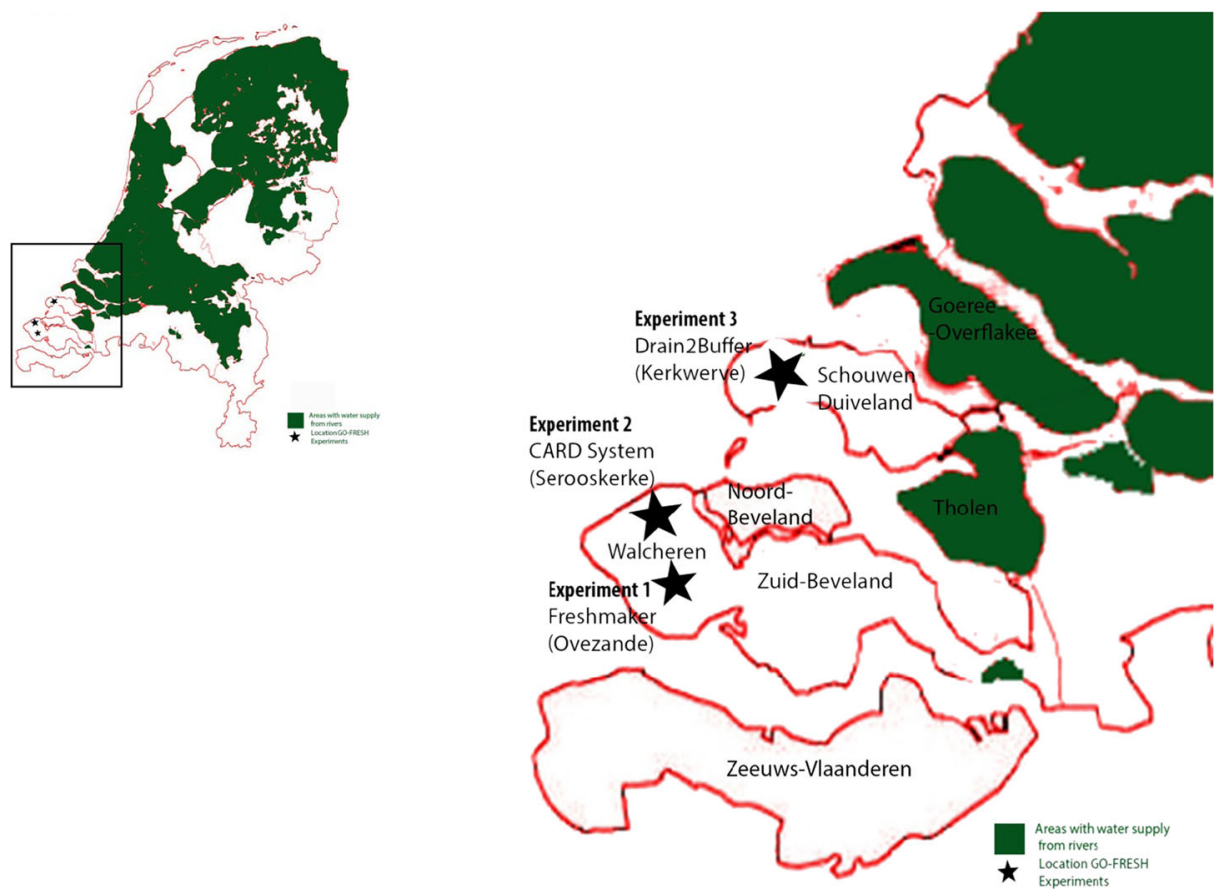

Fig. 1 Freshwater supply areas in the Netherlands (Van Minnen and Ligtvoet 2012). The white areas are dependent on precipitation and groundwater resources and/or artificial water supply (Zeeuws-Vlaanderen). The black stars represent the GO-FRESH experiments 
The probability of agricultural yield reduction and loss of farm income due to water shortage and salinization in these rain-fed areas is therefore larger than the probability in other regions with an external fresh water supply from rivers. The availability of freshwater resources in soil and groundwater bodies will most likely decrease in southwest Netherlands due to prospective climate change and increasing water demand (Oude Essink et al. 2010).

Other reasons to improve freshwater supply at the farm-level, in this part of the Netherlands, are the expected impact of climate change (Kabat et al. 2009) and of the partial recovery of estuarine dynamics in this region (Hommes et al. 2009; Vinke-de Kruijf et al. 2010).

In practice, the application of a technology to improve freshwater supply at a farm depends on its socio-economic feasibility and the behaviour of the farmer. Within the research program 'Knowledge for Climate' (Jeuken Jeuken et al. 2012a; Oude Essink et al. 2014) these aspects were investigated in two projects:

The GO-FRESH project, which stands for Geo-hydrological Opportunities Fresh Water Supply consists of three pilots (2011-2014) with new technologies to improve freshwater supply at farm level (Table 1).

Moreover, the project also contains a so-called feasibility study with the objective to identify and to select socio-economic factors that determine the feasibility of the technologies applied in the pilots. It concerns technologies that buffer winter precipitation surplus in soil and groundwater bodies to be used in summer. By applying this technology, farms become better equipped to cope with precipitation deficits in summer. In each pilot, drainage, infiltration and abstraction technologies, known from geo-hydrological and agricultural engineering, are combined. The pilots are currently still in an experimental stage. The GO-FRESH project participants have worked together for three years (2011-2014).

Within the project 'Balancing supply and demand of freshwater', a survey was conducted in the southwest of the Netherlands to elicit farmers 'risk perceptions and adaptive behaviour to drought (van Duinen et al. 2014; Van Duinen et al. 2015). The survey analyses the attitude of potential users of the new technologies with respect to the feasibility of drought mitigation measures over time at a certain moment (Spring 2013). The survey was conducted amongst

Table 1 Description of the three GO-FRESH experiments

Experiment 1 (Freshmaker): This technology is based upon aquifer storage and recovery (ASR) which involves injection and recovery of freshwater in aquifers via vertical abstraction wells. Although ASR is a proven technology(Pyne 2005), the technique is not yet often used in aquifers in a brackish to saline environment as exemplified in this experiment at a fruit orchard in Ovezande (Zuurbier et al. 2014a; Zuurbier et al. 2014b).

Experiment 2 (CARD system, Controlled Artificial Recharge and Drainage system) concerns storage and infiltration of freshwater in creek deposits with controlled drainage systems at two farms in Serooskerke (horticulture and arable farming). Also, controlled drainage systems and sub-irrigation are a proven technology (Madramootoo et al. 2007; Stuyt and Dierickx 2006) but have never been used to infiltrate fresh water into a saline groundwater environment (Pauw et al. 2015).

Experiment 3 (Drains2buffer) involves increasing shallow rainwater lenses with controlled drainage and has been applied at a farm in Schouwen-Duiveland, Kerkwerve (arable farming). The rainwater storage capacity of the subsurface is increased by drainage of brackish to saline groundwater. This is achieved by positioning the drainage pipes deeper and closer to each other as compared to conventional drainage designs (Oude Essink et al. 2014). The technology is also applied in the North of the Netherlands within the project Spaarwater (ACACIA Water 2014; Velstra et al. 2011). 
agricultural entrepreneurs in the same region were the pilots were initiated (southwest Netherlands).

This paper focuses on socio-economic feasibility. Results of both studies are compared in order to assess how experts, farmers and policy makers evaluate environmental, socioeconomic, and behavioural factors that determine the wider use of water supply technologies at farm level.

\section{Theoretical Framework}

\subsection{Adoption of Technologies}

New technologies spread gradually, reflecting heterogeneity among potential adopters, processes of learning, technological improvement and socio-economic conditions (Rogers 2003; Vreugdenhil et al. 2012). Several studies stemming from various scientific disciplines (Bouma et al. 2011; Kiparsky et al. 2013; Ortt et al. 2008) highlight the importance of economic, behavioural, institutional, and social factors in the adoption of innovations in various sectors, including the water management (Nji and Fonteh 2002; Vreugdenhil et al. 2010a; Vreugdenhil et al. 2010b; Vreugdenhil et al. 2012) and climate adaptation science (Bolson and Broad 2013; Zilberman et al. 2012).

Adaptation to climate change can be defined in many ways (Fankhauser and Schmidt-Traub 2011; International Panel on Climate Change (IPCC) 2007; Nelson et al. 2007. We choose a definition suggested by Zilberman et al. (2012) where adaptation is defined as a response of economic agents and societies to environmental (climate adaptation) or political and socioeconomic changes. Given the inherent uncertainties (Swart et al. 2009), decision making at farm level about adaptation strategies could be defined as a risk management strategy.

Application of micro-economic theory to study the adoption of farm technology, suggests that expected costs and benefits as well as risk aversion are important drivers of farmers' decision-making when facing risks (Just and Zilberman 1983; Liu 2013; Serra et al. 2008; van Duinen et al. 2014).

Typically, these studies assume perfectly rational decision-making in which agents form expectations based on perfect information on the probabilities and potential damages related to extreme weather conditions.

While economic factors are important, it becomes increasingly recognized that decisionmaking in a risk context is seldomly perfectly rational and that behavioural factors such as risk perception along with perceived costs, benefits and self-efficacy affect individual adaptive decision-making (Dang et al. 2014; Gebrehiwot and van der Veen 2015; Grothmann and Patt 2005; Liu 2013; Pidgeon and Fischhoff 2011; Schwarz and Ernst 2009). Research shows, for example, that farmers' drought risk perceptions are biased due to drought risk experience, perceived behavioural control and social networks (Tang et al. 2013; Van Duinen et al. 2015; Wheeler et al. 2013). Biased risk perceptions could give rise to risky behaviour or excessively protective behaviour.

Due to these behavioural factors and imperfect knowledge, farmers, water managers and the developers of a technology might perceive the socio-economic feasibility of an innovative technology differently (De Boer et al. 2010). Also, differences in perceptions regarding crop yield reduction risks may play a role in choices of farmers (Lavee 2010; van Duinen et al. 2012) regarding investments in local freshwater supply technologies. Biases in the perceptions 
of risks (De Boer et al. 2010), costs (Klostermann et al. 2013) and uncertainties about the effectiveness of measures to improve freshwater supply (Lavee 2010), may hamper the adoption and diffusion of these technologies.

\section{Research Approach}

Results from the feasibility and survey studies are combined and compared. Both studies tried to assess attitudes towards innovations in fresh water supply at the farm-level in the southwestern Netherlands in view of climate change, in absence of sufficient empirical data on hydrological efficiciency and crop yield of the applied technologies. The quantification of some of the socio-economic factors were meant to discuss the impact of assumptions. It was not the objective to compare the feasibility of the three technologies.

As the study subject and its context are similar, a case study approach (Flyvbjerg 2006; Yin 2009; Yin 2012) is chosen to synthesize the results. It has to be taken into account that the studies were conducted in different ways.

\section{Approach Feasibility Study}

The feasibility study was conducted between 2011 and 2014 and included active membership (Adler and Adler 1987; Atkinson and Hammersley 1994) within a project team of about 20 people that consisted of technical experts, farmers, civil servants and some students (Table 2).

\subsection{Selection of Feasibility Criteria}

A wide array of criteria can be typified as relevant for the evaluation of the socio-economic feasibility of the investigated technologies. The criteria were identified through discussions with the project participants (Table 2) in workshops and interviews (Oude Essink et al. 2014).

Table 2 actors directly involved in the experiments

\begin{tabular}{|c|c|c|c|}
\hline Funding bodies / regional authorities & Technical Experts & $\begin{array}{l}\text { Target group for } \\
\text { the innovation }\end{array}$ & $\begin{array}{l}\text { Knowledge transfer / } \\
\text { socio-economic } \\
\text { conditions }\end{array}$ \\
\hline Province of Zeeland & Deltares & Meeuwse Trading & $\begin{array}{l}\text { HZ University of Applied } \\
\text { Sciences }\end{array}$ \\
\hline $\begin{array}{l}\text { STOWA (Acronym for Foundation } \\
\text { for Applied Water Research, } \\
\text { founded by Dutch Water boards) }\end{array}$ & KWR Water & $\begin{array}{l}\text { Fruit Cultivation firm } \\
\quad \text { (user technology } 1 \text { ) }\end{array}$ & $\begin{array}{l}\text { ZLTO (Dutch agricultural } \\
\text { interests association) }\end{array}$ \\
\hline Water Board Scheldestromen & ACACIA Water & $\begin{array}{l}\text { Arable farmer (user } \\
\text { echnology 2) }\end{array}$ & Alterra \\
\hline Foundation "Knowledge for Climate" & & $\begin{array}{l}\text { Horticulture (user } \\
\text { technology 2) }\end{array}$ & \\
\hline Municipality Schouwen-Duiveland & & $\begin{array}{l}\text { Arable farmer (user } \\
\text { technology 3) }\end{array}$ & \\
\hline $\begin{array}{l}\text { ZLTO (Dutch agricultural interests } \\
\text { association) }\end{array}$ & & & \\
\hline
\end{tabular}


All selected criteria were evaluated in a qualitative way. In addition, for all three experiments, the criteria directly related to the profitability at farm level were evaluated quantitatively.

\subsection{Assessment of Costs and Benefits of the Application of a Technology at Farm Level}

For each technology (CARD, Drain2buffer, FRESHMAKER), the expected net revenue of additional fresh water supply were estimated for two scenarios (Table 3). In the first scenario, the crop production plan has remained unchanged, while in the second scenario the crop production plan also has been altered to include more profitable crops. In the examples of arable farming, sugar beets were replaced by cauliflower. At the fruit company, on $25 \%$ of the plots apples were replaced by pears (Table 3).

The estimated net revenue reflects the difference between the scenario and the reference situation, i.e. the situation without additional freshwater supply and baseline crop production plan. In the calculations no distinction is made between crop yield reduction caused by drought or by salinity. It is assumed that water nuisance damage is similar and minimized in all scenarios. Moreover (expected) long-term developments on the agricultural market and dynamics in market prices are not taken into account.

The applied farm sizes were the actual farm sizes where the experiments were conducted the applied crop production plans (arable farm 1, fruit farm) are representative for arable farming and fruit cultivation in this area in the Netherlands. The crop production plan of the farm in the DRAIN2BUFFER experiment was not applied because it included crops for which the required data were not available (spinach seed, grass seed).

\subsection{Assumptions to Address Agro-Hydrological Uncertainties}

It was assumed that application of a technology results in an additional freshwater supply of $100 \mathrm{~mm}$, available for irrigation (FRESHMAKER, CARD) or as soil moisture (DRAINS2BUFFER). This irrigation gift quantity is representative for an average (moderately) dry year (Table 4). It is assumed that the three technologies have an equal and modest hydrological performance.

Table 3 Farm properties used in the calculations

\begin{tabular}{|c|c|c|c|}
\hline Farm properties & Fruit farm & Arable farm 1 (Sanderse) & $\begin{array}{l}\text { Arable farm } 2 \\
\text { (Van den Hoek) }\end{array}$ \\
\hline Applied technology & FRESMAKER & CARD & DRAIN2BUFFER \\
\hline Farm size (ha) & 15 & 25 & 75 \\
\hline $\begin{array}{l}\text { Scenario 1: additional } \\
\text { freshwater supply }\end{array}$ & $\begin{array}{l}75 \% \text { Elstar Apples, } 25 \% \\
\text { Conference Pears }\end{array}$ & \multicolumn{2}{|c|}{$\begin{array}{l}\text { Potatoes }(25 \%) \text {, unions }(25 \%) \text {, sugar beets } \\
\quad(25 \%) \text {, winter wheat }(25 \%)\end{array}$} \\
\hline $\begin{array}{l}\text { Scenario 2: Additional freshwater } \\
\text { supply and an altered crop } \\
\text { production plan }\end{array}$ & $\begin{array}{l}50 \% \text { Elstar Apples, } 50 \% \\
\text { Conference Pears }\end{array}$ & \multicolumn{2}{|c|}{$\begin{array}{l}\text { Potatoes }(25 \%) \text {, unions }(25 \%) \text {, winter wheat } \\
\quad(25 \% \text { and } 25 \% \text { cauliflower }\end{array}$} \\
\hline
\end{tabular}


Table 4 Characteristics of drought years that are used in national hydrological studies in the Netherlands (Klijn et al. 2010)

\begin{tabular}{lllll}
\hline & $\begin{array}{l}\text { Precipitation } \\
\text { deficit }\end{array}$ & $\begin{array}{l}\text { Return period (as used } \\
\text { in Dutch models) } \\
\text { (Klijn et al. 2010; } \\
\text { Klijn et al. 2011) }\end{array}$ & $\begin{array}{l}\text { Relative yield } \\
\text { reduction (as used } \\
\text { in Dutch models) } \\
\text { (Jeuken et al. 2012) }\end{array}$ & $\begin{array}{l}\text { Irrigation gift (as used } \\
\text { in Dutch models) } \\
\text { (Massop et al. 2013; }\end{array}$ \\
& & 2.5 & $6 \%$ & 100 \\
\hline Average dry year (1967) & 151 & 6.7 & $?$ & $?$ \\
Moderately dry year (1996) & 199 & 10 & $10 \%$ & 144 \\
Dry year (1949) & 220 & 100 & $24 \%$ & $>200$ \\
Extremely dry year (1976) & 360 & & & \\
\hline
\end{tabular}

\subsection{Yield calculations: arable farms}

For the reference situation (without additional freshwater supply), the figures of the gross production and the gross revenue per hectare for a specific crop were based upon the average yields $(\mathrm{kg})$ and average prices $(€ / \mathrm{kg}$, VAT included) in the period 2007-2011 in the Netherlands (PPO Wageningen UR 2012). The gross revenue per hectare was calculated by subtracting material costs (fertilizers, pesticides, energy use, etc.) and the costs of hired labour from the gross production multiplied by the weighted average price $/ \mathrm{kg}$ (Table 5). The gross revenue is the reward for the input of capital, land and (the farmers own) labour.

With respect to the supply of additional fresh water, it is assumed that, for all selected crops, a supply of $100 \mathrm{~mm}$ water increases the yield between $6 \%$ and $10 \%$ as compared to the reference situation (in the current Dutch climatic conditions). The assumed sensitivity to drought, therefore, is relatively small. Among the most drought-sensitive crops are summer vegetables, leafy vegetables, flower bulbs, fruit and tree crops. The potential gross yield of these crops might decrease by 9 to $38 \%$ due to drought stress (Brouwer and Huinink 2002; Stuyt et al. 2005).

Table 5 Estimated gross revenue per hectare of the crops within the crop rotation plans as used in the scenario's regarding (additional) water supply and changes in crop rotation

\begin{tabular}{|c|c|c|c|c|c|}
\hline \multirow{2}{*}{ Assumed yield increase } & \multirow{2}{*}{$\begin{array}{l}\text { No additional water supply } \\
0 \%\end{array}$} & \multicolumn{4}{|c|}{ With additional water supply } \\
\hline & & $6 \%$ & $10 \%$ & $16 \%$ & $22 \%$ \\
\hline \multicolumn{4}{|c|}{ Source: (PPO Wageningen UR 2012) } & \multicolumn{2}{|c|}{ (Heijerman-Peppelman and Roelofs 2010) } \\
\hline & \multicolumn{5}{|l|}{ Gross revenue $\left(€ h a^{-1}\right)$} \\
\hline Potatoes (consumption) & 4011 & 4277 & 4573 & & \\
\hline Winter wheat & 1147 & 1112 & 1198 & & \\
\hline Cauliflower & 5216 & 5541 & 5893 & & \\
\hline Sugar beet & 1729 & 1770 & 1912 & & \\
\hline Sowing union & 3801 & 4050 & 4346 & & \\
\hline Elstar apple & 1444 & & & 2379 & \\
\hline Conference pear & 7329 & & & & 10,972 \\
\hline
\end{tabular}


The difference between the reference situation and the situation with additional freshwater supply (scenario 1) and/or changed production plan (scenario 2), represents drought damage for up to a moderate dry year (Table 4).

\subsection{Yield calculations: fruit firms}

The difference between the measured averages of the 5-year physical yields (HeijermanPeppelman and Roelofs 2010) of Elstar Apples (16\%) and Conference Pears (22\%) with and without irrigation was used to estimate the effect of an additional freshwater supply of $100 \mathrm{~mm}$ (Table 5). The net revenue of additional freshwater supply was calculated for the situation in which fruit trees are fully established and at full production. Apples and pears need respectively 4 and 6 years to achieve full production (Table 5) (Kipp 1992).

Cost calculations (fruit and arable farming)

The investment costs were estimated from the costs incurred during the construction of the experimental sites. The technical lifetime for all techniques used is set at 15 years in order to assess the annual depreciation.

Annual maintenance, energy and legislation costs are an important uncertainty, as the evaluated techniques have not yet been applied at a large scale. Estimations were made based upon a recent inventory of costs within the Netherlands (Tolk 2013) and cost estimations that were made during the course of the experiments by involved actors.

\subsection{Net Revenue}

In both cases the net revenue is determined as the product of the gross revenue for each crop and the corresponding crop surfaces minus the annual costs of the innovation. The annual costs of an innovation consist of the investment, maintenance and legislation costs. The costs of water supply (i.e. the use of the innovation) are accounted for in the yield calculations.

At present, the uncertainties in the costs and benefits for these three new technologies are still too large to calculate a net present value in a meaningful way with a discount rate. The cost calculations take into account an average inflation of $2.5 \%$ over the entire lifespan of the investment.

\section{Research Approach Survey Study}

To elicit farmers' perceptions of drought risks and attitudes towards adaptive measures, a survey was conducted among 1474 members of a Dutch agricultural organization (division South, ZLTO) during January and February of 2013. TNS-NIPO, a professional organization in the Netherlands specializing in data collection using questionnaires (TNS-NIPO 2014), supported the survey design, web-application, and communication with respondents.

Some of the survey results (Van Duinen et al. 2015) are further explored to examine how the results agree with or differ from the experiences in the GO-FRESH project.

The survey was pre-tested in 12 interviews. After the pre-test, redundant questions were removed and unclear questions were reformulated. Survey requests and reminders were sent by email and by mail (Goeree Overflakkee) with the invitation to participate (online or by post). The 1474 survey requests, elicited 142 replies (response rate $9 \%$ ) (Van Duinen et al. 2015). 
With small samples, response bias may pose a danger. To check the representativeness of the sample, age, education, farm size, farm type and access to an external water supply of the respondents were compared to those of the population in general using data from CBS Statistics Netherlands.

On average, farmers in the sample were slightly younger and better educated than the overall population they were thought to represent, but the differences were found to be small (Van Duinen et al. 2015). In the survey, arable farmers (81\% compared to $70 \%$ ) and those growing fruit and flowers were over-represented compared to farmers growing grass and corn (12\% compared to $26 \%$ of the actual population). Consequently, the response rate was higher for those farms that are more susceptible for drought.

\section{Feasibility Study: Results and Discussion}

Table 6 illustrates the socio-economic factors, which were considered to be important for the feasibility by the GO-FRESH participants.

\subsection{Discussion of Hydrological Performance}

All participants involved (Table 2) were convinced that the hydrological performance of additional freshwater supply at the farm level is an important criterion for the adoption of the three studied technologies at a larger scale. The actors use the same indicator (additional freshwater supply expressed in $\mathrm{m}^{3}$ or $\mathrm{mm}$ ).

In the initial phase, regional authorities had doubts about the hydrological performance of the three experiments. This was because of their experiences with previous comparable experiments (Projectgroep Zoetwateronderzoek 1986; Van Meerten 1986; Vermaas 1987) with disappointing results. However, during the implementation of the results of the experiments, the farmers, researchers and policy makers involved became more convinced that the technologies are promising, despite uncertainties regarding their hydrological performance.

Field measurements also indicate that a significant and promising amount of freshwater was buffered in the subsurface in all three experiments (Table 7). This is also partly explained by the high winter precipitation surplus of 2013 (345 mm). Follow-up research (2015-2016) is scheduled for all 3 experiments in order to assess how the technologies perform under different weather conditions.

To implement the CARD-system, a 7 ha area was used and the development of the freshwater lens below this farm concerned ( $25 \mathrm{ha})$ and the neighbouring farm (11 ha) was monitored from May 2013 to May 2014. The application of the technology is beneficial to the increase of the size of the entire freshwater lens under both farms. Both farms have facilities (deep drains) to extract (irrigation) water from the lens.

The models applied predicted a total volumetric increase of the freshwater lens of about 190,000 $\mathrm{m}^{3}$ after 10 years (Pauw et al. 2015). This implicates that after $1-2$ years enough water is present in the sub-surface for $100 \mathrm{~mm}$ irrigation gift as assumed in the feasibility study.

For the Freshmaker technology, model calculations showed that after 2 years it becomes possible to annually recover $4200 \mathrm{~m}^{3}$ from the subsurface (Zuurbier et al. 2014a). For this specific fruit farm in Ovezande the additional freshwater supply created is sufficient for a 


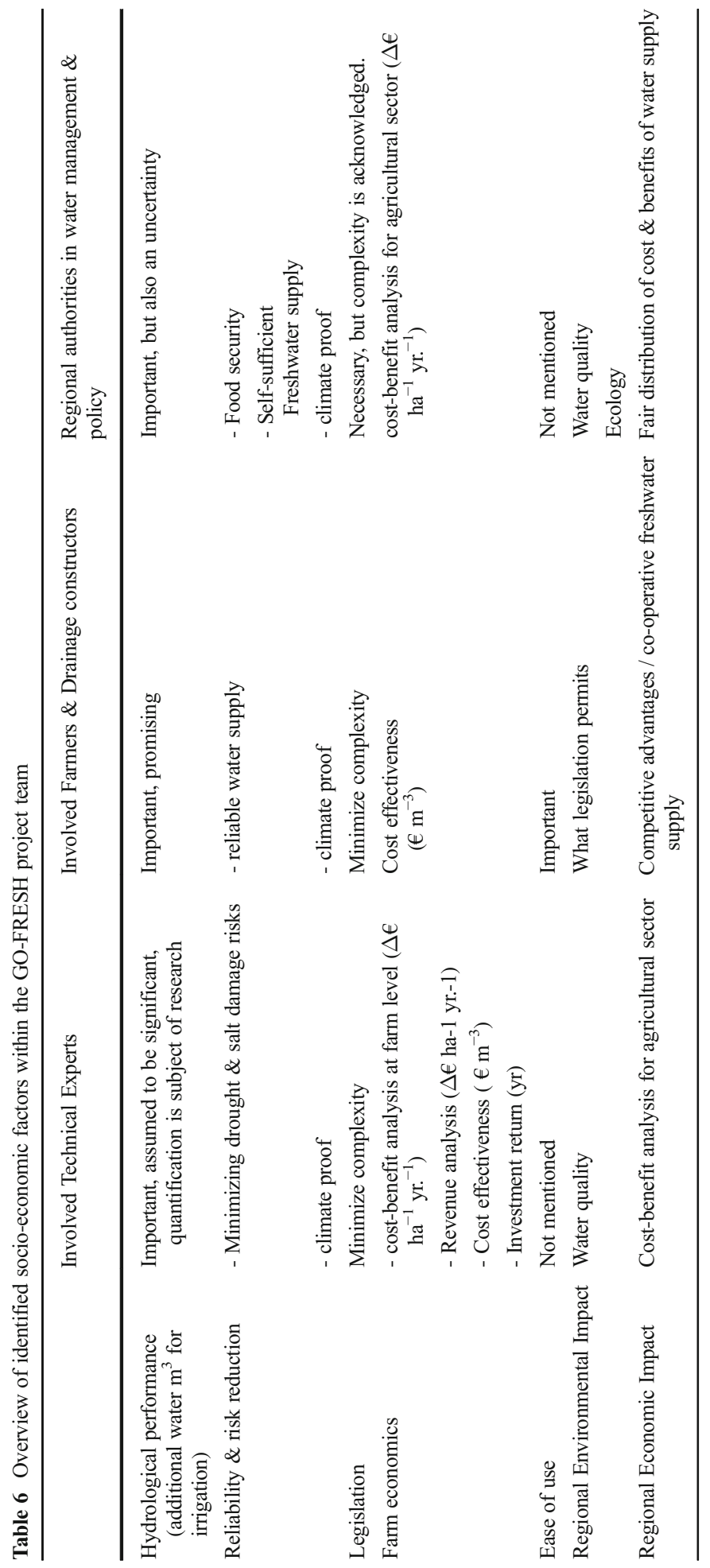


Table 7 Hydrological performance in the three pilot areas

\begin{tabular}{|c|c|c|c|}
\hline & $\begin{array}{l}\text { Irrigation requirement } \\
\text { in a moderate dry } \\
\text { year }(100 \mathrm{~mm})\end{array}$ & $\begin{array}{l}\text { Estimated hydrological } \\
\text { performance }\end{array}$ & $\begin{array}{l}\text { Development } \\
\text { time of } \\
\text { subsurface } \\
\text { water buffer }\end{array}$ \\
\hline $\begin{array}{l}\text { CARD System Serooskerke } \\
\text { (25 ha) (Pauw et al. 2015) }\end{array}$ & $25.000 \mathrm{~m} 3$ & $\begin{array}{l}190,000 \mathrm{M}^{3} \text { Recharge after } \\
10 \text { years }\end{array}$ & 10 years \\
\hline $\begin{array}{l}\text { Drains2Buffer Kerkwerve ( } 75 \text { ha) } \\
\quad \text { (Oude Essink et al. 2014) }\end{array}$ & $75.000 \mathrm{~m} 3$ & $300,000 \mathrm{M}^{3}$ & $4-5$ years \\
\hline $\begin{array}{l}\text { FRESHMAKER Ovezande Fruit } \\
\text { Farm (15 ha)(Zuurbier et al. 2014a) }\end{array}$ & $15.000 \mathrm{~m}^{3}$ & $\begin{array}{l}1700-3000 \mathrm{~m}^{3} \text { successfully } \\
\text { infiltrated and recovered } \\
\text { for irrigation in one season. }\end{array}$ & 1 season \\
\hline
\end{tabular}

moderate dry summer. At first glance the additional water supply (4000 m3) does not meet the water demand $(15,000 \mathrm{~m} 3)$. However, in addition to sub surface storage (Freshmaker), this farm has a water basin $(4500 \mathrm{~m} 3)$. Rainwater is collected in winter. In case of water scarcity in spring or summer the basin can be re-filled with surface water, provided that the salinity is not too high. In case the salinity of the surface water is too high (summer), the basin can be re-filled with the additional water from the Freshmaker. In this specific example, the feasibility of the Freshwater technology benefitted from the presence of surface water and a water basin.

For the DRAIN2BUFFER technology, the first field measurements show that the drainage system performs better than the old drainage system. However, it was not yet possible to determine whether the freshwater lens in the field had increased significantly. Model calculations indicate that a maximum equilibrium of the freshwater lens can be reached in 4-5 years (Oude Essink et al. 2014). If the technology would be applied to the surface area of the farm, it would result in an increase of $300.000 \mathrm{~m}^{3}$ freshwater. In theory, this will be sufficient to present an irrigation gift of $100 \mathrm{~mm}$ in the growing season in a moderate dry summer.

\subsection{Reliability \& Risk Reduction}

The technical experts involved frequently used the reduction of drought and salt damage risks as an argument to apply the technologies. The farmers involved on the other hand, stressed the importance of reliability of freshwater supply. Only secondly, drought or salt damage risks were mentioned by the farmers. The farmers also asked the experts for guarantees on the hydrological performance of the technologies.

\subsection{Legislation}

The current legislation aims to reduce the environmental impact of large-scale withdrawals and infiltration of fresh water on the supplies of drinking water. All GO-FRESH participants agree that current legislation is not suited for small-scale applications of the three experiments.

Different regional authorities are in charge of the implementation (water board, municipality, province), while national authorities are responsible for the formulation of the quality standards for the water to be infiltrated. The regional authorities are cautious granting licenses 
in this early stage of technology development because the environmental impact of large-scale application at more farms in a region is unknown to them.

The level of juridical complexity is different for each technology. The use of the Freshmaker, for example, requires 5 licences for construction (bore holes), infiltration, withdrawal, discharge of brackish water into surface water and withdrawal of freshwater for irrigation. In addition, water quality monitoring is required for infiltration of freshwater and discharges of brackish groundwater into surface water. The application of the CARD and Drains2Buffer require less legislation and associated costs (Zuurbier et al. 2015).

Licenses include water quality standards and limits regarding the volume that is infiltrated or extracted. Monitoring activities are costs for the farmer. Permissions are an agreement between water manager and a farmer that a certain activity is allowed (no costs involved).

\subsection{Farm Economics}

All actors involved agree that the application of the technologies should, in the end, result in a benefit for the agricultural firm involved. However, different socio-economic indicators are used to assess the added value. Socio-economic indicators mentioned are the net revenue for farmers $\left(\Delta € \mathrm{ha}^{-1} \mathrm{yr}^{-1}\right)$ based upon the enumeration of costs and benefits at farm level, cost effectiveness $\left(€ \mathrm{~m}^{-3}\right)$ and the investment return time (years). There was no agreement about what indicator to use preferentially. Although identical terms were used for the identified indicators, sometimes for the participants definitions implicitly are slightly different. For example, the cost-effectiveness of various technologies has been often discussed without information about the hydrological performance of each of the three technologies.

Table 8 presents the calculated economic indicators for the hypothetical firms with arable farming, horticulture and fruit cultivation for different scenarios regarding technology use and crop choice.

Table 8 Economic impacts of additional freshwater supply with applied new technologies (scenario 1) and changed crop rotation (scenario 2)

\begin{tabular}{|c|c|c|c|}
\hline Socio-economic indicators & Fruit Farm (15 ha) & Arable farm (25 ha) & Arable farm (75 ha) \\
\hline Applied technology & $\begin{array}{l}\text { Aquifer storage \& } \\
\text { recovery (ASR) / Fresh } \\
\text { maker }\end{array}$ & $\begin{array}{l}\text { Storage in creek } \\
\text { deposits }\end{array}$ & $\begin{array}{l}\text { Storage in rainwater } \\
\text { lenses }\end{array}$ \\
\hline $\begin{array}{l}\text { Investment costs (euro) (derived from } \\
\text { pilot costs) }\end{array}$ & 56,250 & 50,000 & 187,500 \\
\hline Annual costs technology* (euro) & $6050-12.200$ & $6500-7400$ & $16,600-16,800$ \\
\hline Annual cost/ha technology $\left(€ h a^{l}\right)$ & $400-800$ & $260-300$ & $220-225$ \\
\hline \multicolumn{4}{|c|}{ Scenario 1: additional freshwater supply (technology use) } \\
\hline \multirow[t]{2}{*}{ Net revenue farmer $\left(\Delta 10^{3} € h a^{-1} y r^{-1}\right)$} & & $-0.10-0.17(6 \%)$ & $-0.1(6 \%)$ \\
\hline & $0.8-1.2$ & $0.03-0.07(10 \%)$ & $0.1(10 \%)$ \\
\hline \multicolumn{4}{|c|}{ Scenario 2: additional freshwater supply and changed crop rotation } \\
\hline \multirow[t]{2}{*}{ Net revenue farmer $\left(\Delta 10^{3} € h a^{-1} y r^{-1}\right)$} & & $0.07-0.08(6 \%)$ & $0.9(6 \%)$ \\
\hline & $3.0-3.4$ & $1.0-1.1(10 \%)$ & $1.1(10 \%)$ \\
\hline
\end{tabular}

*Based upon a technical lifetime of 15 years 


\subsection{Discussion of Addressed Cost Indicators}

The calculated cost indicators for the DRAIN2BUFFER and CARD are within the same range as mentioned in other studies $\left(50-500 € \mathrm{ha}^{-1}\right)$, while the estimated costs for Freshmaker application are relatively low compared to other studies (700-2400€ $\mathrm{ha}^{-1}$ ) (Tolk 2013). Maintenance, energy use and legislation costs remain important uncertainties.

Differences in assumptions about investment costs have a low impact on the calculation of the net revenue because they are spread out over a 15 year period in the annual costs (depreciation). It should also be taken into account that farmers will compare the annual costs of additional freshwater supply with other investment options that may increase or maintain yield or farm income, such as crop management, pest management or harvest technologies (Kanellopoulos et al. 2014; Schaap et al. 2013).

\subsection{Discussion of Net Revenues in Arable Farming}

The results indicate that the application of additional fresh water supply (scenario 1) mitigates drought damage (net revenue $\approx 0$ ) in moderate dry years, given the selected crop production plans for arable farming. At the fruit farm, additional the freshwater supply results into a modest revenue increase.

Scenario 2 illustrates that the net revenue of additional water supply can increase when the crop cultivation plan is simultaneously adapted towards more profitable crops for both type of farms. It should be noted that the design of the crop production plan does not only depend on freshwater availability. For example, pears are also very susceptible to pests and diseases. This risk also has an effect on the decision of a farmer regarding his crop production plan choice.

\subsection{Ease of Use}

The participating farmers and ZLTO expressed that the ease of use is an important factor when deciding whether to apply a certain technology or not. More experience is needed before concise statements can be made for a larger group of farmers.

\subsection{Regional Environmental Impact}

Water quality standards for groundwater and surface water are recognized criteria by technical experts, farmers and policy makers, as reflected in existent monitoring protocols for water supply and storage (Table 8). In particular, this is true for the Freshmaker project, where it was also subject of research. The Province of Zeeland also stressed the importance of ecological and landscape impacts when the technologies are applied at larger scale.

\subsection{Regional Economic Impact}

The application of the techniques can increase competitiveness of the agricultural sector in the southwestern Netherlands. However, additional freshwater supplies may also boost freshwater demand at regional level with implications for other water users. The distribution of costs was also brought up as a point of concern. If one farm invests in freshwater storage, the neighbouring farms may profit without sharing costs. Therefore a regulated freshwater supply 
with cost sharing via farm co-operations was also considered. This may accelerate the adoption of these technologies and reduce the legislation costs (cost sharing).

\section{The Survey: Results and Discussion}

\subsection{Drought Risk Perceptions about Yield Reductions in a Dry and very Dry Year}

The survey contained two questions that were designed to reveal farmers' drought risk perceptions. Respondents were asked to give a quantitative estimate of the return period (Fig. 2) and farm income reduction (Fig. 3) for a dry year and an extreme dry year.

Figure 2 shows that respondents did not make a distinction between a dry and extremely dry year in their estimation of the return period. For both meteorological conditions similar estimations were given that ranged between 2 and 15 years (Fig. 3). In hydrological studies (Table 4), a difference of a factor of 10 is assumed regarding years that are characteristic for the return period for a dry and a very dry year, respectively. This assumption is based upon time series analysis of climate data. It can be concluded that respondents tended to overestimate the probability of an extremely dry summer.

The survey respondents estimated an average production loss ranging from 750 euro per ha (arable farmers) up to 3500 euro per ha (fruit farms) in a very dry year (Fig. 3). The average income was $\pm 3000-6000 € \mathrm{ha}^{-1}$ (arable farming) and 15,000-19,000 $€ \mathrm{ha}^{-1}$ (fruit) (LEI Wageningen UR 2014).

On average, farmers expect to suffer approximately $€ 39,000$ damage in a dry year compared to $€ 78,000$ in an extremely dry year. The average annual turnover of the respondents is

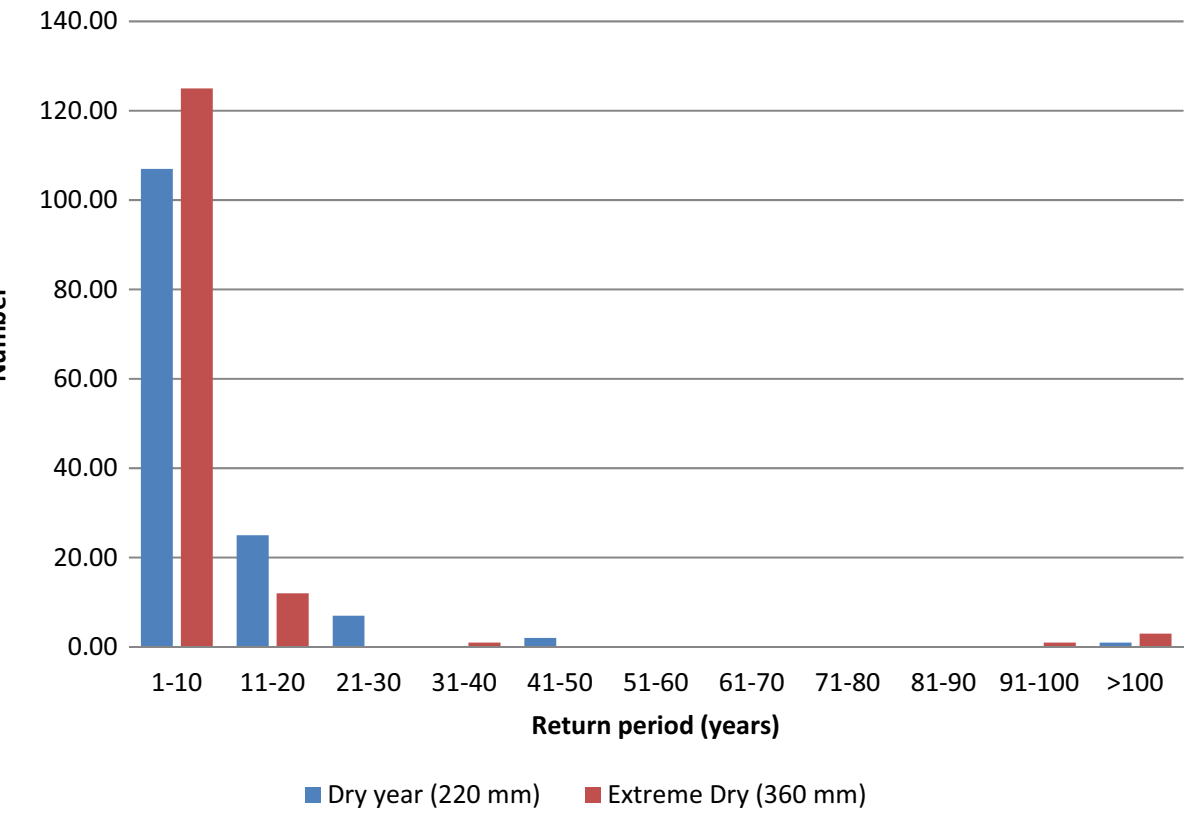

Fig. 2 Frequency distribution of farmers' estimation of the return time of a dry year and an extreme dry year (perceived probabilities) 


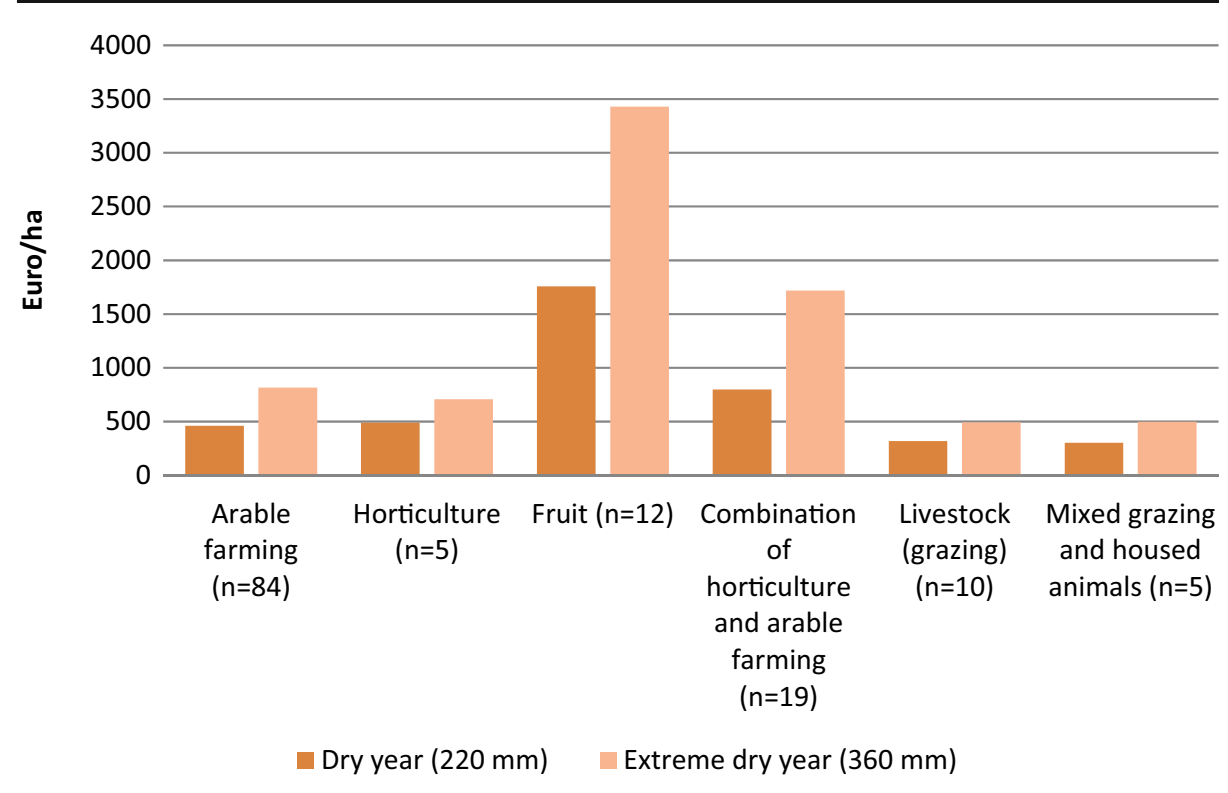

Fig. 3 Estimation of perceived damage by farmers in a dry and extremely dry year (expressed in euro ha $^{-1}$ for different farm types

in the order of $€ 200,000$ to $€ 250,000$. Consequently, income losses amount to some $16-20 \%$ in a dry year and $30-40 \%$ in an extremely dry year.

\subsection{Estimated Income Losses in Period 2003-2012}

Respondents were also asked to estimate income losses as a result of drought for each year from 2003 to 2012 (Table 9).

There seems no correlation between annual cumulative summer deficit (April-September) and the estimated average production loss by the respondents (Table 9). An alternative

Table 9 Annual summer deficit in growing season in the Netherlands (Source: Royal Netherlands Meteorological Institute (KNMI)) and average estimated production loss in survey

\begin{tabular}{lllll}
\hline year & Summer deficit (KNMI) & \# resp. & Avg est. production loss & Sd \\
\hline 2003 & $227 \mathrm{~mm}$ & 24 & 18.0 & 7.0 \\
2004 & $12 \mathrm{~mm}$ & 10 & 15.0 & 8.4 \\
2005 & $52 \mathrm{~mm}$ & 8 & 13.8 & 8.7 \\
2006 & $117 \mathrm{~mm}$ & 32 & 19.2 & 11.5 \\
2007 & $0 \mathrm{~mm}$ & 11 & 17.1 & 8.4 \\
2008 & $109 \mathrm{~mm}$ & 11 & 12.4 & 7.0 \\
2009 & $197 \mathrm{~mm}$ & 19 & 17.1 & 12.9 \\
2010 & $45 \mathrm{~mm}$ & 30 & 19.5 & 10.8 \\
2011 & $17 \mathrm{~mm}$ & 43 & 16.5 & 12.0 \\
2012 & $13 \mathrm{~mm}$ & 11 & 11.5 & 8.8 \\
\hline
\end{tabular}


indicator for drought is the standardised drought indicator (SPI) (McKee et al. 1993). The SPI is the deviation of the amount of precipitation from the mean for a specified time period.

In Fig. 4 the monthly SPI values are presented for the period 2000-2014 from the KNMI weather station in Vlissingen that is situated in the neighbourhood of where the experiments are performed. The mean and standard deviation were derived from the data for the 1962-2014 period.

In 2003, 2006, 2009 and 2011, spring (March-May) was dry (Fig. 4). In these years the number of respondents that reported production loss nearly doubled. However, the average perceived yield reduction $( \pm 18 \%$ ) did not differ significantly compared to other years.

Based on the cumulative summer deficit of $200 \mathrm{~mm}, 2009$ can be typified as a 'moderately dry year'. About 19 respondents reported drought damage. This is a low response rate compared to years with similar or higher summer deficits (Table 9). The SPI time series (Fig. 4) indicate a mild drought $(0<\mathrm{SPI}<-1)$ in the beginning of the growing season (MarchJune), while in July and August severe to extreme drought was measured $(-1.5<\mathrm{SPI}<-3)$. The low number of farmers that reported drought damage despite a summer deficit of $200 \mathrm{~mm}$ is therefore probably explained by the fact that mostly fruit growers experienced drought damage in late summer. Most arable farmers within this sample experienced little or no drought damage in spring 2009.

The year 2011 (cumulative summer deficit $=11 \mathrm{~mm}$ ) can be classified as an average dry/wet year. Intuitively, one would expect a low number of respondents that report drought damage. Surprisingly, however, the response rate was high (43 respondents). The SPI-time series indicate a period of severe drought $(-1.5<\mathrm{SPI}<-2)$ in the first part of growing season (March-May).

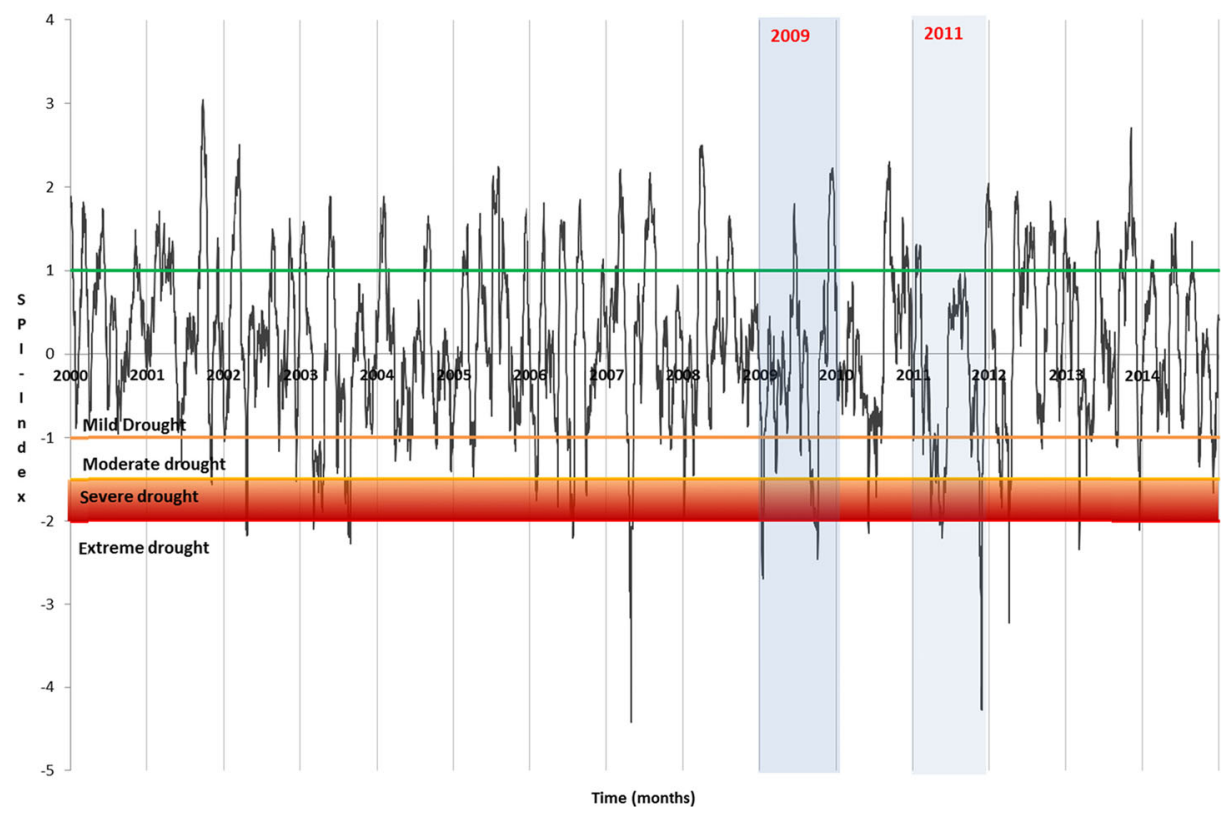

Fig. 4 SPI time series for the Weather station at Vlissingen in the period 2000-2014 (Alterra et al. 2015; Wesseling et al. 2011) 


\subsection{Attitudes towards the Innovative Measures}

In the survey, famers indicated their level of familiarity with the adaptation measures, including the three studied GO-FRESH technologies, by multiple choices with six options (Fig. 5).

On a 7 -point scale $(1=$ low; $7=$ high $)$. the farmers were asked to indicate the effectiveness and the costs of each the two measures. Based on these answers, a cost-effectiveness (CE)score was calculated for each of the three measures. This is the ratio between perceived effectiveness and perceived costs. The value of the CE lies between 1/7 and 7 .

\subsection{Aquifer storage and recovery (FRESHMAKER)}

About $50 \%$ of the farmers are not aware of the existence of this measure. Approximately $40 \%$ of the respondents conclude that this measure is not applicable to their farm (Fig. 5). The CEratio is below 1 for the majority of the respondents, indicating that they perceive the costs to be higher than the effectiveness of the measures. Perceptions were not found to differ between arable farming, fruit cultivation and horticulture.

\subsection{Storage and infiltration of freshwater in creek deposits (CARD SYSTEM)}

Of the respondents, $85 \%$ was aware of the possibility to store and infiltrate fresh water in creek deposits (Fig. 5). The majority of farmers indicate that this measure is not applicable to their farm, probably because they are not located in the vicinity of a creek or sand ridge. The measure is perceived to be more cost-effective than FRESHMAKER and DRAIN2BUFFER. The cost-effectiveness ratio (CE) is above 1 for the majority of the respondents.

Storage in rainwater lenses with controlled drainage

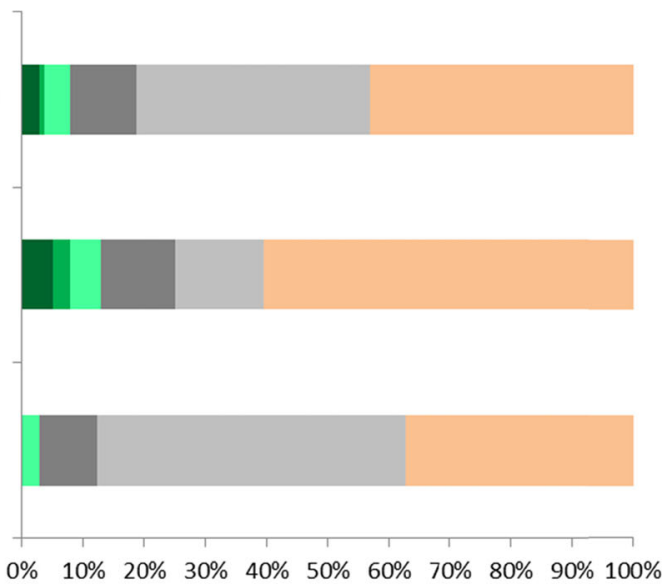

- already adopted this measure

n considered to adopt this measure

not aware of the existence of the measure v plan to adopt this measure within five years'

naware of the existence of the measure

Not relevant for my farm

Fig. 5 Indicated level of familiarity for Aquifer storage and recovery (FRESHMAKER), Storage and infiltration of freshwater in creek deposits (CARD SYSTEM) and Freshwater storage in rainwater lenses with controlled drainage (DRAIN2BUFFER) $(n=139)$ 


\subsection{Freshwater storage in rainwater lenses with controlled drainage (DRAIN2BUFFER)}

A large part of the farm sample is unfamiliar with this type of measure and thinks it is not applicable to their farm (Fig. 5). Furthermore, the perceived cost-effectiveness of this type of measure is low $(<1)$.

\section{Conclusions}

The feasibility study and the survey were compared to analyse how experts, farmers and policy makers evaluate environmental, socioeconomic and behavioural factors that determine the wider use of climate compatible water supply technologies at farm level.

For the participants involved in the feasibility study and the respondents of the survey, it was difficult to quantify yield reduction risks in terms of probability, expected yield reduction and causes of yield reduction. This also applies to the involved scientists.

The respondents did not make a distinction in terms of drought damage between 'dry' or 'moderately dry years'. In contrast to agro-hydrological models, in the period 2003-2012 the estimated average yearly drought damage (12-17\%) was more or less similar among respondents. The number of respondents reporting drought damage is a more reliable indicator of agricultural drought impact than the cumulative precipitation deficit, in particular when it is combined with the standardized precipitation index (SPI).

Furthermore, the survey reveals that farmers do not make a significant distinction between the probability of occurrence of a dry and extremely dry year. The survey respondents overestimate the risks of an extremely dry year by a factor 10 .

These observations illustrate differences in understanding between the indicated drought damage risks by farmers compared to the used risk values in water management and research.

In the feasibility study it appeared to be difficult to select a single economic indicator for cost(-effectivenes) all involved actors agreed upon (low level of common understanding). In the survey 'costs' and 'effectiveness' were assessed separately in qualitative terms. This approach avoids this discussion and it is recommended to use this approach in feasibility studies.

The costs, and hence the cost-effectiveness, depend also on the existing water supply facilities at farm level. It is therefore difficult to identify generic cost estimates in both approaches. For example, if farms already have a controlled drainage system in place, the investment costs to apply CARD and DRAINS2BUFFER will be lower compared to the presented examples. On the other hand, within the pilot with the CARD system, costs were also reduced because the controlled drainage system was designed for two farms.

In the pilot with the FRESHMAKER, cost savings were possible because a sufficiently large water basin was present at the location studied. However, not all companies in this region have a water basin with the desired capacity. It is therefore recommended to add uncertainty ranges to cost estimates in feasibility studies in combination with cost saving opportunities.

The calculated CE ratios for the three technologies were low $(<1)$ because most survey respondents were unfamiliar with the technologies in contrast to the farmers that participated in the GO-FRESH experiments. The level of common understanding of and confidence in the technical and socio-economic feasibility increased amongst the farmers, policy makers and experts that were involved in GO-FRESH. However, 
for farmers reliable freshwater supply and supportive legislation are the most decisive socio-economic criteria for a future investment.

Both the survey and the feasibility study illustrate that a positive impact of additional freshwater supply on the net revenue of an agricultural farm strongly depends on the type of farm (fruit, arable farming, and horticulture) and the crop cultivation plan. This insight offers opportunities to increase the positive impact of additional freshwater supply by simultaneously adapting the crop cultivation plan.

Acknowledgments This research was financially supported by the foundation 'Knowledge for Climate', the Province of Zeeland, ZLTO, Water board Scheldestromen, the municipality of Schouwen-Duiveland, the ministry of Economic Affairs and the ministry of Infrastructure and Environment. We thank Lieselotte Tolk (ACACIAWater) and Gualbert Oude Essink (Deltares) for their comments. A language check was done by Peter Dijkwel (retired researcher from University of Virginia, USA).

Open Access This article is distributed under the terms of the Creative Commons Attribution 4.0 International License (http://creativecommons.org/licenses/by/4.0/), which permits unrestricted use, distribution, and reproduction in any medium, provided you give appropriate credit to the original author(s) and the source, provide a link to the Creative Commons license, and indicate if changes were made.

\section{References}

ACACIA Water (2014) Spaarwater. Rendabel en duurzaam agrarisch watergebruik in een verziltende omgeving. Acacia Water. http://www.spaarwater.com/pg-27227-7-72161/pagina/spaarwater_rendabel_en_duurzaam_ watergebruik.html. Accessed 06-08-2014 2014

Adler PA, Adler P (1987) Membership roles in field research. Sage Publications, Newbury Park, CA

Alterra, STOWA, Provincie Zuid-Holland, Provincie Noord Holland, Provincie Utrecht (2015) Droogtemonitor. Wageningen UR. http://www.droogtemonitor.nl/index.php/nl/. Accessed 26-0620152015

Atkinson P, Hammersley M (1994) Ethnography and participant observation. In: Denzin NK, Lincoln YS (eds) Handbook of qualitative research. Sage Publications, Thousand Oaks, pp. 248-261

Beersma JJ, Buishand TA (2004) Joint probability of precipitation and discharge deficits in the Netherlands. Water Resour Res 40:W12508. doi:10.1029/2004wr003265

Bolson J, Broad K (2013) Early Adoption of Climate Information: Lessons Learned from South Florida Water Resource Management Weather Clim Soc 5:266-281 doi:10.1175/Wcas-D-12-00002.1

Bouma J, van Altvorst AC, Eweg R, Smeets PJAM, van Latesteijn HC (2011) The Role of Knowledge When Studying Innovation and the Associated Wicked Sustainability Problems in Agriculture Adv Agron 113: 283-312. doi:10.1016/B978-0-12-386473-4.00011-7

Brouwer F, Huinink JTM (2002) Opbrengstdervingspercentages voor combinaties van bodemtypen en grondwatertrappen. Geactualiseerde HELP-tabellen en opbrengstdepressiekaarten. Alterra / Expertise Centrum LNV, Wageningen

CBS, LEI (2014) Arable crops; production to region. [cited 03-09-2014]. Available from: http://statline.nl/ StatWeb/publication/?VW=T\&DM=SLEN\&PA=7100eng\&LA=EN

Cominelli E, Conti L, Tonelli C (2013) Galbiati M. Challenges and perspectives to improve crop drought and salinity tolerance New Biotechnol 30:355-361. doi:10.1016/j.nbt.2012.11.001

Dang HL, Li E, Nuberg I, Bruwer J (2014) Understanding farmers' adaptation intention to climate change: a structural equation modelling study in the Mekong Delta. Vietnam Environmental Science \& Policy 41:1122. doi:10.1016/j.envsci.2014.04.002

De Boer J, Wardekker J, Van der Sluijs JP (2010) Frame-based guide to situated decision-making on climate change Global Environmental Change doi: 10.1016/j.gloenvcha.2010.03.003

De Louw, PGB (2013) Saline seepage in deltaic areas. Preferential groundwater discharge through boils and interactions between thin rainwater lenses and upward saline seepage. $\mathrm{PhD}$ Thesis, Vrije Universiteit

De Louw PGB, Eeman S, Siemon B, Voortman BR, Gunnink J, van Baaren ES (2011) Oude Essink GHP. Shallow rainwater lenses in deltaic areas with saline seepage Hydrol Earth Syst Sci 15:3659-3678. doi:10. 5194/hess-15-3659-2011 
Fankhauser S, Schmidt-Traub G (2011) From adaptation to climate-resilient development: The costs of climateproofing the Millennium Development Goals in Africa. Clim Dev 3:94-113. doi:10.1080/17565529.2011. 582267

Flyvbjerg B (2006) ) Five misunderstandings about case-study research. Qual Inq 12:219-245. doi:10.1177/ 1077800405284363

Gebrehiwot T, van der Veen A (2015) Farmers prone to drought risk: why some farmers undertake farm-level risk-reduction measures while others not? Environ Manag 55:588-602. doi:10.1007/s00267-014-0415-7

Grothmann T, Patt A (2005) Adaptive capacity and human cognition: The process of individual adaptation to climate change. Global Environ Chang 15:199-213. doi:10.1016/j.gloenvcha.2005.01.002

Heijerman-Peppelman G, Roelofs, PFMM (2010) Kwantitatieve informatie Fruitteelt 2009/2010. Wageningen UR (Praktijkonderzoek Plant \& Omgeving), Randwijk

Hommes S, Vinke-de Kruijf J, Otter H, Bouma G (2009) Knowledge and Perceptions in Participatory Policy Processes: Lessons from the Delta-Region in the Netherlands. Water Resour Manag 23:1641-1663. doi:10. 1007/s11269-008-9345-6

International Panel on Climate Change (IPCC) (2007) Climate change 2007: impacts, Adaptation and Vulnerability. Working Group II Contribution to the fourth Assessment Report of the Intergovernmental Panel on Climate Change. Cambridge University Press, Cambridge, United Kingdom

Jeuken A et al. (2012) Balancing supply and demand of fresh water under increasing drought and salinisation in the Netherlands. Research Programme Knowledge for Climate, Utrecht

Just RE, Zilberman D (1983) Stochastic structure, Farm Size and Technology Adoption in Developing Agriculture Oxford Economic Papers 35:307-328 doi:10.2307/2662653

Kabat P et al. (2009) Dutch coasts in transition. Nat Geosci 2:450-452. doi:10.1038/ngeo572

Kanellopoulos A, Reidsma P, Wolf J, van Ittersum MK (2014) Assessing climate change and associated socio-economic scenarios for arable farming in the Netherlands: An application of benchmarking and bio-economic farm modelling European Journal of Agronomy 52, Part A:69-80 doi: $10.1016 /$ j.eja.2013.10.003

Kiparsky M, Sedlak DL, Thompson BH, Truffer B (2013) The innovation deficit in urban water: the need for an integrated perspective on institutions. Organizations, and Technology Environ Eng Sci 30:395-408. doi:10. 1089/ees.2012.0427

Kipp JA (1992) 30 Years Fertilization and Irrigation in Dutch Apple Orchards - a Review Fert Res 32:149-156 doi:10.1007/Bf01048777

Klijn F, Kwadijk JCJ, De Bruijn K, Hunink J (2010) Overstromingsrisico's en droogterisico's in een veranderend klimaat verkenning van wegen naar een klimaatveranderingsbestendig Nederland. Deltares, Delft

Klijn F, Ter Maat J, Van Velzen EH (2011) Zoetwatervoorziening Nederland landelijke knelpuntenanalyse 21ste eeuw. Deltares, Utrecht

Klostermann JEM, Veraart JA, Cofino WPM (2013) "Zoutwatervrees". Zekerheden en onzekerheden rond het zout maken van het Volkerak-Zoommeer. Eindrapport. Alterra / Kennis voor Klimaat, Wageningen

Lavee D (2010) The effect of water supply uncertainty on farmers' choice of crop portfolio. Agric Water Manag 97:1847-1854. doi:10.1016/j.agwat.2010.07.001

LEI Wageningen UR (2014) Rekenmodule LEI berekening Standaard Opbrengst. Wageningen UR. http://www3. lei.wur.nl/neg/Default.aspx. Accessed 04-09-2014 2014

Liu EM (2013) Time to Change What to Sow: Risk Preferences and Technology Adoption Decisions of Cotton Farmers in China. Rev Econ Stat 95:1386-1403

Madramootoo CA, Johnston WR, Ayars JE, Evans RO, Fausey NR (2007) Agricultural drainage management, quality and disposal issues in North America. Irrig Drain 56:S35-S45. doi:10.1002/Ird.343

Massop HTL, Schuiling C, Veldhuizen AA (2013) Potentiele beregeningkaart 2012 - update landelijke potentiele beregeningskaart voor het NHI op basis van landbouwmeitellingen 2010. Alterra (Wageningen UR), Wageningen

McKee TB, Doesken NJ, Kleist J (1993) The relationship of drought frequency and duration to time scales Paper presented at the Eighth Conference on Applied Climatology, California,

Nelson DR, Adger WN, Brown K (2007) Adaptation to environmental change: Contributions of a resilience framework. Ann Rev Enviro Resour 32:395-419. doi:10.1146/annurev.energy.32.051807.090348

Nji A, Fonteh MF (2002) Potential and constraints to the adoption of water harvesting technologies in traditional economies. Discov Innovat 14:202-214

Ortt JR, Shah CM, Zegveld MA (2008) Commercializing breakthrough technologies: Scenarios and strategies Manag Tech 2:207-221 doi:10.1142/9789812790545 0013

Oude Essink GHP, van Baaren ES, de Louw PGB (2010) Effects of climate change on coastal groundwater systems: a modeling study in the Netherlands. Water Resour Res 46:16. doi:10.1029/2009wr008719

Oude Essink GHP et al. (2014) GO-FRESH - Valorisatie kansrijke oplossingen voor robuuste zoetwatervoorziening. Deltares/KWR/ACACIA Water/ HZ University of Applied Science / Alterra, Utrecht 
Pauw P, van Baaren E, Visser M, de Louw PB, Essink GPO (2015) Increasing a freshwater lens below a creek ridge using a controlled artificial recharge and drainage system: a case study in the Netherlands. Hydrogeol J:1-16. doi:10.1007/s10040-015-1264-Z

Pidgeon N, Fischhoff B (2011) The role of social and decision sciences in communicating uncertain climate risks Nat Clim Chang 1:35-41 doi: 10.1038/NCLIMATE1080

PPO Wageningen UR (2012) De Kwantitatieve Informatie Akkerbouw en Vollegrondsgrondsgroenteteelt 2012 (KWIN-AGV 2012). Praktijkonderzoek plant en omgeving (Wageningen UR), Lelystad

Pyne RDG (2005) Aquifer Storage Recovery - A guide to Groundwater Recharge Through Wells., 2nd edition edn. ASR Systems LLC, Gainesville, Florida

Rogers EM (2003) Diffusion of innovations fifth Edition edn. Free Press, New York

Schaap BF, Reidsma P, Verhagen J, Wolf J, van Ittersum MK (2013) Participatory design of farm level adaptation to climate risks in an arable region in The Netherlands Euro J Agron 48:30-42 doi:10.1016/j.eja.2013.02. 004

Schwarz N, Ernst A (2009) Agent-based modeling of the diffusion of environmental innovations - An empirical approach. Technol Forecast Soc 76:497-511. doi:10.1016/j.techfore.2008.03.024

Serra T, Zilberman D, Gil JM (2008) Differential uncertainties and risk attitudes between conventional and organic producers: the case of Spanish arable crop farmers. Agr Econ 39:219-229. doi:10.1111/j.1574-0862. 2008.00329.x

Stunt LCPM et al. (2005) Transitie en toekomst van de deltalandbouw: indicatoren voor de ontwikkeling van de land- en tuinbouw in de Zuidwestelijke delta van Nederland. Alterra, Wageningen.

Stuyt LCPM, Dierickx W (2006) Design and performance of materials for subsurface drainage systems in agriculture. Agric Water Manag 86:50-59. doi:10.1016/j.agwat.2006.06.004

Swart R, Bernstein L, Ha-Duong M, Petersen A (2009) Agreeing to disagree: uncertainty management in assessing climate change, impacts and responses by the IPCC. Clim Chang 92:1-29. doi:10.1007/s10584008-9444-7

Tang J., Folmer H., J. X (2013) Estimation of awareness and perception of water scarcity among farmers in the Guanzhong plan, China, by means of a structural equation model J Environ manag 126:55-62 doi:10.1016/j. jenvman.2013.03.051

TNS-NIPO (2014) TNS-NIPO Marktonderzoek marketing informatie en business insights. http://www.tns-nipo. com/. Accessed 19-08-2014 2014

Tolk L (2013) Zoetwater verhelderd. Maatregelen voor zoetwater zelfvoorzienendheid in beeld. ACACIA-Water / Kennis voor Klimaat, Gouda

Van Bakel PJT, Kselik RAL, Roest CWJ, Smit AAMFR (2009) Review of crop salt tolerance in the Netherlands. Alterra (Wageningen UR), Wageningen

van Duinen R, Filatova T, van der Veen A (2012) The role of social interaction in farmers' climate adaptation choice. In: Seppelt R, Voinov AA, Lange S, Bankamp D (eds) International Congress on Environmental Modelling and Software - Managing Resources of a Limited Planet, Sixth Biennial Meeting, Leipzig, Germany, 2012. International Environmental Modelling and Software Society (iEMSs), pp 2493-2504

van Duinen R, Filatova T, Geurts P, van der Veen A (2014) Coping with drought risk: empirical analysis of farmers' drought adaptation in the south-west Netherlands Regional Environmental Change:1-13 doi:10.1007/s10113-014-0692-y

Van Duinen R, Filatova T, Geurts P, van der Veen A (2015) Empirical analysis of Farmers' drought risk perception: objective factors. Personal Circumstances, and Social Influence Risk Analysis 35:741-755. doi:10.1111/risa.12299

Van Meerten JJ (1986) Kunstmatige infiltratie in Kreekruggen. MSC Thesis, TH-Delft

Van Minnen J, Ligtvoet W (2012) Effecten van klimaatverandering in Nederland: 2012. PBL Netherlands Environmental Assessment Agency, Den Haag

Velstra J, Groen J, De Jong K (2011) Observations of salinity patterns in shallow groundwater ans drainage water from agricultural land in the northern part of the Netherlands. Irrig Drain Syst 60:51-58. doi:10. 1002/ird.675

Vermaas JCJ (1987) Kwelscherm voor kreekrug op Walcheren. Landbouwuniversiteit Wageningen, Wageningen

Vinke-de Kruijf J, Hommes S, Bouma G (2010) Stakeholder participation in the distribution of freshwater in the Netherlands. Irrig Drain Syst 24:249-263. doi:10.1007/s10795-010-9097-3

Visser SJ, van Tuinen ESJ (2012) Second problem analysis freshwater supply and demand for the South West Delta and Rijnmond-Drechtsteden. [In Dutch: 2e fase lange termijn probleemanalyse zoetwatervoorziening Zuidwestelijke Delta \& Rijnmond-Drechtsteden - Regionale probleemanalyse Deltaprogramma Zoetwater]. Publisher: Programmabureau Zuidwestelijke Delta, p. 135 [Cited: 03-09-2014.] Available from: www. zwdelta.nl/bibliotheek:publicaties.htm 
Vreugdenhil H, Slinger J, Kater E, Thissen W (2010a) The influence of scale preferences on the Design of a Water Innovation: a case in Dutch River management (vol 46, pg 29, 2010). Environ Manag 46:827-827. doi:10.1007/s00267-010-9565-4

Vreugdenhil H, Slinger J, Thissen W, Rault PK (2010b) Pilot Projects in Water Management Ecology and Society 15(3):13. http://www.ecologyandsociety.org/vol15/iss3/art13

Vreugdenhil H, Taljaard S, JH S (2012) Pilot projects and their diffusion: a case study of integrated coastal management in South Africa. Int J Sustainable Development 15:148-171

Wesseling JG, Oostindie K, Ritsema CJ (2011) The Drought Monitor. A standardized procedure to characterize drought and wet conditions. [In Dutch: De Droogte Monitor: een gestandariseerde methode omperiodes van droogte en natheid te identificeren en weer te geven], Alterra report, Wageningen, the Netherlands, p. 31. Available from: http://edepot.wur.nl/292771

Wheeler S, Zuo A, Bjornlund H (2013) Farmers' climate change beliefs and adaptation strategies for a water scarce future in Australia. Global Environmental Change 23:537-547. doi:10.1016/j.gloenvcha.2012.11.008

Yin RK (2009) Case study research : design and methods. Applied social research methods, vol 5, 4th edn. Sage Publications, Los Angeles, Calif

Yin RK (2012) Applications of case study research. 3rd edn. SAGE, Thousand Oaks, Calif

Zilberman D, Zhao JH, Heiman A (2012) Adoption Versus Adaptation, with Emphasis on Climate Change Annu Rev Resour Econ 4:27-53 doi:10.1146/annurev-resource-083110-115954

Projectgroep Zoetwateronderzoek (1986) Zoetwaterinfiltratieproef Kapelle. Kort verslag van een onderzoek naar de mogelijkheden voor de kunstmatige infiltratie van zoetwater in een kreekrug. Stichting voor bedrijfsontwikkeling in de Landbouw, Goes

Zuurbier KG, Kooiman J, Groen M, Maas B, Stuyfzand PJ (2014a) Enabling Successful Aquifer Storage and Recovery of Freshwater Using Horizontal Directional Drilled Wells in Coastal Aquifers. J Hydrol Eng 10. doi:10.1061/(ASCE)HE.1943-5584.0000990, B4014003

Zuurbier KG, Zaadnoordijk WJ, Stuyfzand PJ (2014b) How multiple partially penetrating wells improve the freshwater recovery of coastal aquifer storage and recovery (ASR) systems: a field and modeling study. J Hydrol 509(509):430-441

Zuurbier K, van der Schans M, Paalman M, de Putter P, te Winkel T, Velstra J, Oude Essink G (2015) Technischjuridische handreiking risicobeoordeling 'ondergrondse waterberging'. Stowa rapport;2015-35. Stichting Toegepast Onderzoek Waterbeheer, Amersfoort 